Note

\title{
Attraction of Neomegalotomus parvus (Westwood) (Heteroptera: alydidae) to cow urine and ammonia
}

\author{
Jovenil José da Silva ${ }^{1}$; Iara Cintra de Arruda-Gatti ${ }^{1}$; Adriana Yatie Mikami ${ }^{1}$; Aline Pissinati ${ }^{1}$; \\ Antônio Ricardo Panizzi²; Mauricio Ursi Ventura ${ }^{3 *}$ \\ ${ }^{1}$ UEL/CCA - Programa de Pós-Graduação em Agronomia. \\ ${ }^{2}$ Embrapa Soja - Lab. Bioecologia de Percevejos, C.P. 231 - 86001-970 - Londrina, PR - Brasil. \\ ${ }^{3}$ UEL/CCA, Depto. de Agronomia, C.P. 6001 - 86051-970 - Londrina, PR - Brasil. \\ *Corresponding author <mventura@uel.br>
}

\begin{abstract}
The alydid bug parvus (Westwood) is not easily detected in the field and the discovery of attractants may be a suitable way to monitor this species. The attraction of $N$. parvus to traps (transparent, transparent green and yellow) baited with cow urine and ammonia was studied in two field trials. Traps were placed near a terrace with pigeon pea plants (Cajanus cajan L.). Tap water, $\mathrm{NaCl} 10 \%$ aqueous solution (w/v), cow urine, and ammonia ( $\mathrm{NH}_{4} \mathrm{OH} 1 \%$ aqueous solution) were tested as attractants in yellow, transparent and transparent green traps. Green traps baited with cow urine caught more bugs than yellow and transparent traps (3.2 and 7.2 times more, respectively), and more bugs than traps of the same color with just water (no captures) or $\mathrm{NH}_{4} \mathrm{OH}$ solution (14.5 times more). Traps baited with ammonia caught more bugs than traps with water: 14.4, 4.7 and 6.7 times more than transparent green, yellow, and transparent traps, respectively, or $\mathrm{NaCl}$ solution: 3.9, 7.6 and 6.2 times, respectively. Both ammonia and cow urine are attractive to $N$. parvus and may be tested to monitor the bugs in the field.
\end{abstract}

Key words: semiochemical, attractant, trap color

\section{Atração de Neomegalotomus parvus (Westwood) (Heteroptera: alydidae) por urina de vaca e amônia}

\begin{abstract}
RESUMO: O percevejo alidídeo Neomegalotomus parvus (Westwood) não é facilmente detectado no campo e a descoberta de atraentes pode ser uma forma adequada para monitorar a espécie. A atração de $N$. parvus a armadilhas (transparentes, verde transparente e amarela) iscadas com urina de vaca e amônia foi estudada em dois experimentos em campo. Armadilhas foram colocadas próximas a um terraço com plantas de feijão-guandu (Cajanus cajan L.). Água corrente, solução aquosa de $\mathrm{NaCl} 10 \%$ (p/v), urina de vaca e amônia (solução aquosa de $\mathrm{NH}_{4} \mathrm{OH}$ 1\%) foram testadas como atraentes em armadilhas amarelas, transparentes e transparentes verdes foram utilizadas. Armadilhas verdes iscadas com urina capturaram mais insetos do que armadilhas amarelas e transparentes (3,2 e 7,2 vezes mais, respectivamente), e mais insetos do que armadilhas da mesma cor com apenas água (zero insetos) ou solução de $\mathrm{NaCl}$ (14,5 vezes mais). Armadilhas iscadas com amônia capturaram mais insetos do que armadilhas com água: 14,4; 4,7 e 6,7 vezes mais em verde transparente, amarela e transparente, respectivamente, ou solução de $\mathrm{NaCl}: 3,9$; 7,6 e 6,2 vezes, respectivamente. Amônia ou urina de vaca são atrativas para $N$. parvus e podem ser testadas para monitorar o percevejo no campo.

Palavras-chave: semioquímicos, atraente, cor de armadilha
\end{abstract}

\section{Introduction}

Alydidae are coreoid heteropterans associated with Leguminosae (Schaefer, 1980; Schaefer and Mitchell, 1993). The neotropical species Neomegalotomus parvus (Westwood) has been reported on common beans, Phaseolus vulgaris L. (Paradela Filho et al., 1972); soybean, Glycine max (L.) Merrill (Panizzi, 1988); pigeon pea, Cajanus cajan (L.) Mill. and lablab, Dolichus lablab L. (Santos and Panizzi, 1998); pig bean, Canavalia ensiformes (L.) DC. and indigo, Sesamum indicum L. (Santos, 1996). N. parvus is also reported to damage soybean (Santos and Panizzi, 1998) and common bean seeds
(Paradela Filho et al., 1972), by affecting their quality.

The presence of $N$. parvus is not easily detected in the field because these insects fly when disturbed making population survey difficult to conduct. A new monitoring method would be useful for estimating population density and detecting the presence of $N$. parous in a particular area or on a specific host plant.

Cow urine has been proposed as attractant for stink bug species that are pests of soybean (Corrêa-Ferreira et al., 2003). Based on these captures, pest control measures can be implemented. Results of studies evaluating the responses of $N$. parvus to traps baited with cow urine and ammonia in the field are herein reported. 


\section{Material and Methods}

Experiments were carried out in Londrina, state of Paraná, Brazil $\left(23^{\circ} 19^{\prime} \mathrm{S}, 51^{\circ} 12^{\prime} \mathrm{W}\right)$. Traps consisted of 2$\mathrm{L}$ plastic bottles in the following color pattern: transparent green, yellow, and transparent. Transparent and transparent green bottles were discarded PET containers. Yellow traps were the transparent bottles painted golden yellow. Bottles had four square openings $\left(2 \mathrm{~cm}^{2}\right)$ and were placed $17 \mathrm{~cm}$ above the ground fixed to wooden stakes $5 \mathrm{~m}$ apart from a terrace with pigeon pea (Cajanus cajan L.) plants.

When experiments were installed, pigeon pea plants contained green and mature pods. The attractants $(300$ $\mathrm{mL}$ ) were placed in the bottom of each bottle. In the first experiment (April 15, 2007) the attractants used were: tap water, $\mathrm{NaCl} 10 \%$ aqueous solution (w/v), and cow urine. In the second experiment (October 10, 2007), the same attractants were tested adding $\mathrm{NH}_{4} \mathrm{OH} 1 \%(\mathrm{w} / \mathrm{v})$. Four replicates were set up and traps were maintained for three days in the field. Assessments were carried out three days after the installation of traps, when adult bugs were counted and removed.

Trials were set up on a randomized, complete block design. Distance between traps was $5 \mathrm{~m}$ within a block and $15 \mathrm{~m}$ between blocks. A two-way ANOVA was performed for the study of the interactions between trap colors and attractants followed by Tukey test $(p<0.05)$ to compare means (Tukey, 1949).

\section{Results and Discussion}

In the first experiment, significant effect of the factors attractant, trap color, and their interaction was observed $(p<0.05)$. Transparent green traps lured with cow urine caught 3.2 and 7.2 times more insects than yellow and transparent traps, respectively. Green traps lured with cow urine caught more insects than traps of the same color with just water or salt water, in which captures were negligible or did not occur (Table 1). In previous studies, green vessel water traps caught more male $N$. parvus than traps of other colors, except yellow. Yellow traps also caught more insects than blue, black, and silver traps (Ventura and Panizzi, 2004). A positive interaction between trap color and attractant was also reported for Diabrotica virgifera virgifera LeConte (Hesler and Sutter, 1993) and D. speciosa Germar (ArrudaGatti et al., 2006).

In the second experiment, only attractant effect was significant $(p<0.05)$. Probably, the ammonia was so strong an attractant that the effects of color were made not significant. Traps lured with ammonia yielded 14.4, 4.7, and 6.7 more captures for transparent green, yellow, and transparent traps, respectively, than traps of the same color pattern carrying just water (Table 2). The ammonia was a stronger attractant than urine, probably because higher concentration of active products in the ammonia in comparison to cow urine. Further investigations should address different ammonia concentrations for trapping $N$. parvus. Differently of the first experiment, cow urine was not attractive to $N$. parvus. Seasonal variation in the climatic conditions or physiological state of the bugs may be related to these conflicting responses.

Apparently, the attraction of $N$. parous to cow urine and ammonia is related to protein alternative search by the insect. This behavior may occur in the absence of major hosts, i.e., leguminous plants (Schaefer, 1980; Schaefer and Mitchell, 1993). Adults and nymphs were found feeding on conspecific nymphs and adult cadavers (Ventura and Panizzi, 2004). These authors also reported that second instar nymphs deprived of leguminous seeds, fed exclusively on dead nymphs and reached the third instar, demonstrating the importance of the alternative food for $N$. parvus nutrition. This insect was

Table 1 - Mean number ( \pm standard error) of adults of $N$. parvus caught during three days of capture per trap of three different colors and baited with three attractants.

\begin{tabular}{lccc}
\hline Trap color & Water & $\mathrm{NaCl}$ solution & Cow urine \\
\hline Transparent green & $0.00( \pm 0.00) \mathrm{aB}$ & $0.50( \pm 0.58) \mathrm{aB}$ & $7.25( \pm 1.93) \mathrm{aA}$ \\
Yellow & $0.00( \pm 0.00) \mathrm{aA}$ & $0.00( \pm 0.00) \mathrm{aA}$ & $2.25( \pm 0.71) \mathrm{bA}$ \\
Transparent & $0.25( \pm 0.50) \mathrm{aA}$ & $0.25( \pm 0.50) \mathrm{aA}$ & $1.00( \pm 0.41) \mathrm{bA}$ \\
\hline
\end{tabular}

Different upper case letters in the same line and lower case letters in the same column indicate differences according (Tukey test, $p$ $<0.05, \mathrm{n}=4)$.

Table 2 - Mean number ( \pm standard error) of adults of $N$. parvus caught during three days of capture per trap of different colors and baited with four attractants.

\begin{tabular}{lcccc}
\hline \multirow{2}{*}{ Trap Color } & \multicolumn{4}{c}{ Attractant } \\
\cline { 2 - 5 } & Water & NaCl solution & Cow urine & Ammonia \\
\hline Transparent green & $1.75( \pm 0.48) \mathrm{b}$ & $6.50( \pm 2.60) \mathrm{b}$ & $10.00( \pm 1.96) \mathrm{b}$ & $25.25( \pm 9.01) \mathrm{a}$ \\
Yellow & $4.00( \pm 2.83) \mathrm{b}$ & $2.50( \pm 0.65) \mathrm{b}$ & $4.25( \pm 1.38) \mathrm{b}$ & $19.00( \pm 6.89) \mathrm{a}$ \\
Transparent & $3.25( \pm 1.44) \mathrm{b}$ & $3.50( \pm 1.19) \mathrm{b}$ & $3.00( \pm 1.08) \mathrm{b}$ & $21.75( \pm 3.28) \mathrm{a}$ \\
\hline
\end{tabular}

Different letters in the same line indicate differences (Tukey test, $p<0.05, \mathrm{n}=4$ ). 
also found aggregated in groups of 30-40 adults, apparently feeding on dog feces and carrion after soybean harvest (Ventura and Panizzi, 2004).

Cannibalism and omnivory were also reported in other Alydidae. For instance, Megalotomus quinquespinosus (Say) was observed feeding on other adults when food plants were not available (Yonke and Medler, 1965). Megalotomus quinquespinosus adults together with Alydus eurinus (Say) were observed on decomposing animal and fecal matter (Yonke and Medler, 1968). Schaefer (1980) suggested that Alydidae are attracted to feces and carrion due to their water and concentrated semi liquid protein content. Additionally, their gregarious behavior and rapid movements (or locomotion) probably enable this type of exploration. Alydidae bugs produce rancid secretions (mostly shortchain fatty acids) from the metathoracic scent glands and noted that they are attracted to carrion and feces (Aldrich, 1995).

Ammonia is a by-product of protein decomposition and is known as attractant to other insects. For instance, the Mediterranean fruit fly, Ceratitis capitata (Wiedemann) (Diptera: Tephritidae), was shown to be attracted by ammonia (Mazor et al., 1987). Attraction of Anastrepha spp. (Diptera: Tephritidae) to human urine and chicken feces also suggest attraction to ammonia (Piñero et al., 2003). The apple maggot, Rhagoletis pomonella (Walsh) (Diptera: Tephritidae) was attracted by traps baited with ammonium carbonate (Yee et al., 2006). In conclusion, ammonia and cow urine could be used as attractants in traps for monitoring and detecting $N$. parvus in the field.

\section{Acknowledgements}

To Samuel Roggia and Wilson Ponzenato for assistance, and Daniel R. Sosa Gomez, Maria Cristina Neves and Flávio Moscardi for critical review of the manuscript.

\section{References}

Aldrich, J.R. 1995. Chemical communication in the true bugs and parasitoid exploitation. In: Carde, R.T.; Bell, W.J., eds. Chemical ecology of insects II. Chapman \& Hall, New York, NY, USA.

Arruda-Gatti, I.C.; Silva, F.A.C.; Ventura, M.U. 2006. Responses of Diabrotica speciosa to a semiochemical trap characteristics. Brazilian Archives of Biology and Technology 49: 975-980.
Corrêa-Ferreira, B.S. 2003. Soja Orgânica: Alternativa para o Manejo dos Insetos Pragas. Embrapa Soja, Londrina, PR. Brazil. p.83

Hesler, L.S.; Sutter, G.R. 1993. Effect of trap color, volatile attractants and type of toxic bait dispenser on captures of adults rootworm beetles (Coleoptera: Chrysomelidae). Environmental Entomology 22: 743-750.

Mazor, M.; Gothilf, S.; Galun, R. 1987. The role of ammonia in the attraction of females of Mediterranean fruit fly to hydrolylsate baits. Entomologia Experimentalis et Applicata 43: p.25-29.

Panizzi, A.R. 1988. Biology of Megalotomus parvus (Hemiptera: Alydidae) on selected

leguminous food plants. Insect Science and its Application.9: 279285.

Paradela Filho, O.; Rossetto, C.J.; Pompeu, A.S. 1972. Megalotomus parvus Westwood (Hemiptera, Alydidae), vetor de Nematospora coryli Peglion em feijoeiro. Bragantia 31: p.5-102.

Piñero, J.; Aluja, M.; Vázquez, A.; Equihua, M.; Varón, J. 2003. Human urine and chicken feces as fruit fly (Diptera: Tephritidae) attractants for resource-poor growers. Journal of Economic Entomology 96:.334-340.

Santos, C.H. 1996. Desempenho de Megalotomus parvus Westwood (Hemiptera: Alydidae) em plantas hospedeiras e danos à soja, Glycine $\max$ (L.) Merrill. MSc. Disseratation., Universidade Federal do Paraná, Curitiba, PR. Brazil. 85p. (In Portuguese, with Summary in English).

Santos, C.H.; Panizzi, A.R. 1998. Danos qualitativos causados por Neomegalotomus parvus (Hemiptera: Alydidae) on wild and cultivated legumes. Annals of the Entomological Society of America.91: 445-451.

Schaefer, C.W. 1980. The host plants of the Alydinae, with a note on heterotypic feeding aggregations (Hemiptera: Coreidae: Alydidae). Journal of the Kansas Entomological Society 53: 115-122.

Schaefer, C.W.; Mitchell, P.L. 1993. Food plants of the Coreoidae (Hemiptera: Heteroptera). Annals of the Entomological Society of America 76: 591-615.

Tukey, J.W. 1949. One degree of freedom for non-additivity. Biometrics.5: 232-242.

Ventura, M.U.; Panizzi, A.R. 2004. Responses of Neomegalotomus parvus (Hemiptera: Alydidae) to color and male-lured traps. Brazilian Archives of Biology and Technology 47: 1516-8913.

Yee, W.L.; Landolt, P.J.; Darnell, T.J. 2006. Attraction of Rhagoletis pomonella (Diptera: Tephritidae) and non- target flies to traps baited with ammonium carbonate and fruit volatile lures in Washington and Oregon. Journal of Agricultural and Urban Entomology 23: 133-149.

Yonke, T.R.; Medler, J.T. 1965. Biology of Megalotomus quinquispinosus. Annals of the Entomological Society of America 58: 222-224.

Yonke, T.R.; Medler, J.T.1968. Biologies of three species of Alydus in Wisconsin. Annals of the Entomological Society of America 61: 526-531.

Received April 08, 2008

Accepted September 16, 2009 